\title{
The analysis of entrepreneurship course towards entrepreneurship intention of the students
}

\author{
Charly Hongdiyanto \\ Faculty of Business and Management, Ciputra University \\ charly@ciputra.ac.id
}

Received: April, 2020; Accepted: June, 2020; Published: March, 2021

DOI: https://doi.org/10.24123/jmb.v20i1

\begin{abstract}
This research purpose is to analyze the development of entrepreneurship intention of the student through entrepreneurship course. The research subjects are the students, the lecturers of Entrepreneurship course and the coordinator of Entrepreneurship Course in Ciputra University. The research uses qualitative descriptive study. This research result shows that the development of entrepreneurship intention of the student through entrepreneurship course in Ciputra University is different between one to another. It depends on the student him/herself. Ciputra University already used and gives the best method to facilitate the students, but students who want to learn more about entrepreneurship is the one that can develop their entrepreneurship intention.
\end{abstract}

Keywords: entrepreneurship intention, entrepreneurship education, entrepreneurship course.

\begin{abstract}
Abstrak
Tujuan dari penelitian ini adalah untuk menganalisa perkembangan minat kewirausahaan siswa melalui kelas kewirausahaan. Subjek dari penelitian ini adalah mahasiswa dari Universitas Ciputra, fasilitator dari kelas kewirausahaan, dan koordinator dari kelas kewirausahan di Universitas Ciputra. Penelitian ini menggunakan penelitian deskriptif kualitatif. Hasil dari penelitian ini menunjukan fakta bahwa peran minat kewirausahaan mahasiswa melalui kelas kewirausahaan di Universitas Ciputra berbeda antara satu mahasiswa dengan mahasiswa yang lain. Hal ini tergantung pada siswa itu sendiri, apakah mereka ingin belajar lebih banyak dan mengembangkan minat kewirausahaan mereka sendiri atau tidak. Universitas Ciputra sudah memberikan yang terbaik untuk memfasilitasi mahasiswa, namun mereka yang ingin belajar lebih mengenai minat kewirausahaan adalah mereka yang bisa mengembangkan minat kewirausahaan mereka.
\end{abstract}

Kata Kunci: minat kewirausahaan, pendidikan kewirausahaan, kelas kewirausahaan 


\section{INTRODUCTION}

In this globalization era, countries are competing to give the best prosperity for the life of the citizen. One of the most important factors is economic sector. Entrepreneurship and economic development are intimately related (Jerinabi \& Shanti, 2012); "Entrepreneurial process is a major factor in economic developed and the entrepreneur is the key to economic growth of a country". In additional to individual and organizational level success, the creation of new enterprises by entrepreneurs is important for local, regional, and national economic development (Matlay, 2005; Szopa, Karwowski \& Barbe, 2015). Entrepreneurship can be a way for entrepreneur to employ others and can be job creators (Kelley, Singer \& Herrington, 2016). Entrepreneurs will not only create a job for themselves, but they also provide jobs to others to reduce poverty, unemployment rate and improve the economic growth rate (Chandra, 2013). From those paradigms, entrepreneurship is very important for an economic development for a country. The simple explanation of entrepreneur is someone who is brave in taking risk to open a business (Eroglu \& Picak, 2011). Taking risk mans that the person must be considering many aspects before start a business, this must be performed without fear and anxious (Hongdiyanto, 2014). The activity of entrepreneurship can be done either individually or in group. To summerize it, an entrepreneur is someone who is able to look, utilize and create business opportunities (Hongdiyanto, 2018).

Several groups of Indonesian people are already aware about the importance of entrepreneurship through the economic development for a country. This entrepreneurship awareness makes some of people want to become an entrepreneur. One of the ways to become an entrepreneur is by joining formal education. Many studies have been performed to find out what attributes or characteristic contributed in shaping a person in becoming an entrepreneur (Astebro et al., 2014; Hongdiyanto, 2018). Dealing with this issue, government certainly has tried many policies and regulations to create new entrepreneurs. One of the way to increase number of entrepreneur is by introducing the concept of entrepreneurship in the education system (Ekpiken \& Ukpabio, 2015).

In Ciputra University, students can enhance their entrepreneurship intention and learn more about entrepreneurship by entrepreneurship course or "Reboan" or E-Wednesday class. Students are divided into several guild or classes based on their own entrepreneurship intention such as food, technology, fashion, trading and social. At those classes, students may form entrepreneurship groups that consist of 1-5 persons and do their own entrepreneurship project based on their own passion. Ciputra University entrepreneurial classes are also supported by entrepreneur in residence (the owner of venture businesses) and professional lecturer that expertise at those sector; they are called as facilitator. Every week, students get lessons about entrepreneurship and able to apply it in their own entrepreneurship project. Besides that, every 
week students have a chance to do mentoring with the facilitator which can help them and give some advice to solve problems in their entrepreneurship project. It can be seen that the influence of the facilitator is very important in influencing students' interest to become entrepreneurs.

Based on data in 2016 researcher get from School of Entrepreneurship and Humanity Department (SEH) in Ciputra University, there are 232 entrepreneurship groups in 3rd semester and 282 entrepreneurship groups in 5th semester. Some of entrepreneurship groups can continue their entrepreneurship project until they graduate from Ciputra University, but some of them may not make it. From the 2nd semester through the 3rd semester, 55 percent of groups decide to seperate while from the 4th semester through the 5th semester, 65 percent of the groups decide to continue their entrepreneurial project.

The researcher performed a preliminary survey randomly in Ciputra University with 25 respondents, which shows 73 percent of the students tended to have entrepreneurship intention before joining Ciputra University. Researchers can conclude that not all the students have entrepreneurship intention before joining Ciputra University. Students that have entrepreneurial intention, will have higher entrepreneurial intention after joining the entrepreneurial education. Therefore, educators should give more attention and motivate students to be an entrepreneur (Patricia \& Silangen, 2016).

From the research that has been described by previous authors, a lot of research concluded that entrepreneurship education provides significant influence on increasing student's intention in becoming entrepreneurs. In addition, a student might have the intention before he/she gets an entrepreneur education. If those students supported by appropriate education, it might even increase the previous intention. However, these studies were not conducted in Surabaya and all are quantitative research. Therefore, researchers are interested in making this study to try to close the existing gap; location and method. In addition, not all business projects formed during the education process in Ciputra University last until graduation. Researcher also want to analyze why this problem occurred. The object in this research are the students themselves, facilitator and coordinator of the entrepreneurship course who designed the system. Based on the background that has been explained previously, this research purpose is to analyze the development of entrepreneurial intention of the student through entrepreneurship course. Researcher wants to explore the entrepreneurial intention before and after the students take the entrepreneurship education.

There are several previous journals used to be the benchmark for this research. The first research aims to understand, how entrepreneurship education and entrepreneurial development models affect entrepreneurial intention (Efrata et al., 2016). From this study, the researchers conclude that entrepreneurship education in public universities directly is still not able to increase student entrepreneurial intention. Entrepreneurship 
education gives benefit for the students by increasing self-perception about entrepreneurship abilities (perceived feasibility) to increase student intention to become entrepreneurs. At this study, the researchers also conclude that the existence of entrepreneurial role models affect to increase student's entrepreneurial intention, it is necessary to present role model with close character to students. Students can learn knowledge, skills, abilities, and skill from the entrepreneurial role model. The second research aim to know the influence of lecturer's competence and student attitudes on entrepreneurship class through the development on students' entrepreneurial spirit in the implementation of project-based learning (Purwanto, 2015). The researcher concludes that lecturer's competence is very influenced through the development of students' entrepreneurial spirit. The lecturer of entrepreneurship class supposed to be an entrepreneur too, so the lecturer has theoretical and practice capability and then can combine them. The entrepreneurship class also contains theoretical, study case and practice (learning by doing). The approaching method shouldn't use lecture style teaching, but lecturer can use projectbased learning method. The next study aimed to know the student's intention to be an entrepreneur (Rosmiati, Junias, \& Munawar, 2015). This study shows a result that the first semester accounting students is less intention in entrepreneurship, because most of them does not know and understand about entrepreneurship. Several students have intention on entrepreneurship, because of their own experience.

Entrepreneurship is a process of action that entrepreneur undertakes to establish his enterprise and an entrepreneur also has creative and innovative response (Chandra, 2013). Entrepreneurship can also be defined as an ability to discover, create or invent opportunities and exploit them to the society benefit and can bring prosperity to the innovator and his organization. Therefore, entrepreneurship is an important thing in this era, in which an entrepreneur can discover and develop every opportunity and bring prosperity not only for the entrepreneur itself, but also for the society.

Entrepreneurship can also be defined as a process that can happen to every people either on their own willingness or inside organizations to pursue the opportunities without depends on the resources they currently control (Weber, 2012). Weber explained that "Entrepreneurship is a discovery, evaluation, and exploitation of opportunity that can create a better goods and services by a natural individual by the creation of a new organization." Entrepreneurship is not just appearing as an individual, but as an organization, people can show entrepreneurship.

Entrepreneurial intention is a conscious awareness and conviction that people have to make a new business and make it real at the future (Gek, 2014). There are seven main factors of entrepreneurial intention; (1) Risk taking, it is an individual tendency to take a risk. When a person tolerate a higher risk, he is more inclined to the entrepreneurship. (2) Selfefficacy, the power to produce a desired effect. Self-efficacy can be 
defined into five dimensions of searching, planning, marshaling, implementing people, and implementing finance. (3) Attitude, an individual association about entrepreneur, (4) Behavioral Control, the measurement of every individual how easy and can be success to run a business. (5) Need for Achievement, the entrepreneurship inclined by the need for achievement. (6) Proactiveness, people have their entrepreneurial behavioral intentions. (7) Locus of Control, people control their own self, so the success depends on their own action (Remeikiene, Startiene, \& Dumciuviene, 2013).

Entrepreneurship is both teachable and learnable, entrepreneurship is not magic and mysterious, and entrepreneurship also does not relate with the genes (Weber, 2012) Entrepreneurship is a discipline and it can be learned. People already started too aware about his fact, so people start to join the entrepreneurial education and entrepreneurial seminar. The graduates with an entrepreneurship major tend to start a new business and have stronger entrepreneurial intentions than other graduates. It means that entrepreneurship education is a strategy at education institutes to increase entrepreneurial intentions among students. Entrepreneur education is not just about business management or make a new business, but it's about learning to integrate experience, skills, and knowledge (Gek, 2014). Entrepreneurship education is a formal programmed that make student have skill and knowledge to recognize the opportunities, knows the customer insight, have networking, knows the market, make ideas, develop business plan, run a business and do evaluation (environmental, institutional, and political issues).

There are 3 types of entrepreneurship education approaching; (1) The Normative Approach, entrepreneurship education will be approach by teaching and monitoring the production process of business plan. With this approach, students will learn about how to propose a new product or service, the financial strategies, organizational, marketing. (2) The Experiential Approach, this approach also can define as an informal education, where students may learn knowledge, skills, attitudes, and insight based on the daily experiences. In this approach, students may face the trial and error and it is incorporated of the experience process. (3) Contingency Approach, this approach uses tools that become a navigation and development of path that unpredictable, so students can learn based on those case. So this approach may use modules that provide the systematic method of the learning, so students may explore and learn more based on the other case or based on the real case. Entrepreneurial educations in university affect the intention and attitudes of the student through entrepreneurship, it also affects the desirability of the students to make their own business (Gek, 2014).

\section{RESEARCH METHODS}

This is a qualitative research, in which the end result of this research is descriptive data. This method is chosen by the researcher, because the 
researcher wants to understand the role of entrepreneurship intention through entrepreneurship course of the student in Ciputra University. The research subjects are: (1) The students of Ciputra University who already passed the third E- Wednesday class. The researcher chooses this terms, because students already know the E-Wednesday class situation and curriculum that differentiate based on grouping or guild. (2) The facilitator that teaches minimum 2 semesters on E-Wednesday class based on guild. Researcher chooses this term, because the facilitator that teach minimum 2 semesters, should know about the learning system and the students' response to the entrepreneurship course in Ciputra University. (3) The coordinator of entrepreneurship course in Ciputra University that in charge on make E-Wednesday class curriculum based on grouping or guild.

The technique used for data collection is interview assisted with interview guide that was prepared by the researcher. Interview was conducted to obtain the necessary information and data. Prior to conducting interview, the researcher determines in advance whether the informant in accordance with the criteria. Researcher explains the intent and purpose of this study. If the informant agrees to be interviewed, researcher and informant sign the contract. Then the researcher will conduct interview with informant. The interview process will be recorded for documentation purposes and to help researcher in writing transcripts. The validity of qualitative research needs to be verified; triangulation can be a method to verify the validity of a research. From the triangulation method, researcher uses the triangulation of source (Sugiyono, 2013).

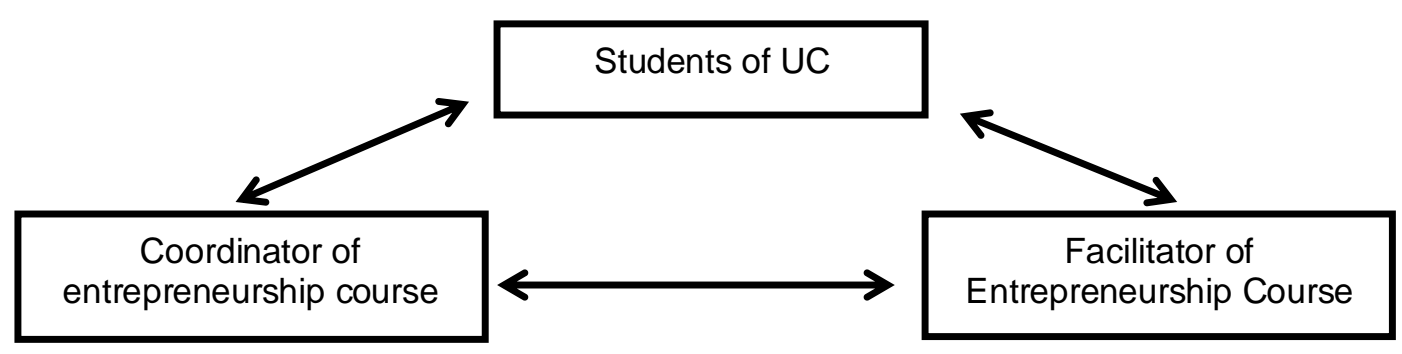

Figure 1. Triangulation of Source

Source: Data Processed

In this research, researcher will shows the research process, interview recording, transcript, documentation, and research result to the thesis adviser as the auditor to do the assessment and make sure that this research is reliable. From the data obtained from interviews, the data will be analyzed through the following process: (1) Data Reduction, at this step, researcher reduces the data without losing the information from the data context. (2). Data Display, researcher displays the data, organize, compress, and assemble the information. This data display helps the researcher to do the analysis. (3), Withdrawal/ Verification Conclusion, after all of those steps, researcher will make a conclusion and must be verified. 
Table 1. Informant's Description

\begin{tabular}{lllll}
\hline Coding & Informant's Initial & Sex & $\begin{array}{c}\text { Semester } \\
\text { (student) }\end{array}$ & Status \\
\hline B & B A & M & - & Coordinator of E. Course \\
N & N M & F & - & Coordinator of E. Course \\
C & C & F & - & Coordinator of E. Course \\
R & R P & M & - & Facilitator of E. Course \\
H & H W & M & - & Facilitator of E. Course \\
A & A B & F & 8 & Student \\
P & P & M & 6 & Student \\
F & F L & F & 6 & Student \\
S & S M & M & 6 & Student \\
\hline
\end{tabular}

Source: Data Processed

Table 1 provide information regarding informant's description while Table 2 provide interview guidance in which researcher able to modify the questions. The data collection process begins with the selection of respondents according to predetermined criteria. The number of respondents is 9 people; consists of 3 course coordinators, 2 facilitator and 4 students. Then the researcher makes an agreement to conduct the interview process. The location of the interview was in the Ciputra University campus environment. During the interview process, the researcher has requested permission to do a voice recording as evidence of an interview process. The length of the interview process is between 20 45 minutes per person.

\section{RESULT AND DISCUSSIONS}

Entrepreneurial intention is a conscious awareness and conviction that people have to make a new business and make it real at the future Gek (2014). Based on the data analysis, researcher finds a fact that most of respondent have a high entrepreneurship intention before joining Ciputra University. Three of four students already have entrepreneurial intention, as what respondent $A$ and $F$ mentioned. "Emmm minat ya. Aku emang dari awal masuk UC karena ngrasa bakalan dapet 2 ilmu sekaligus gitu. Jadi karena emang tujuanku waktu itu psikologi jadi aku ingin dapet psikologinya dan aku pingin belajar entrepreneurnya. Waktu itu ketemunya baru UC karena yang nyampe promosinya ke kita adalah UC gitu. Jadi ya ada sih" (A) and "Eeee iya sih suka, suka itu suka kayak bikin-bikin apa buka bisnis buat cari uang sendiri" (F).

After joining the entrepreneurship course in Ciputra University, some of the students want to know more about entrepreneurship and can develop their entrepreneurship intention. As Mentioned by respondent S: "Ya berkembang sih, soale kan dapet dukungan juga dari fasilitator terus dapet kayak eee tips dan trik dari fasilitator buat tau trik-triknya biar bisnis e isa semakin berkembang." But, after all the developing of the students' 
entrepreneurship intention depends on the students itself as mentioned by respondent $P$ : "Kalo mengenai mahasiswa itu juga variatif, jadi satu fasilitator misalnya handle beberapa, beberapa mahasiswa itu ada yang bisa di dorong dengan cepat, ada yang agak susah ndorongnya, ada yang ehmm kurang bisa di dorong, jadi variatif."

Table 2. Interview Guidance

\begin{tabular}{|c|c|c|c|}
\hline No & Coordinator & Facilitator & Students \\
\hline 1 & $\begin{array}{l}\text { Entrepreneurship } \\
\text { course learning } \\
\text { system at Ciputra }\end{array}$ & $\begin{array}{l}\text { The learning system in } \\
\text { Ciputra University }\end{array}$ & $\begin{array}{l}\text { Prior interest in } \\
\text { entrepreneurship }\end{array}$ \\
\hline 2 & $\begin{array}{l}\text { The reason the system } \\
\text { chosen }\end{array}$ & $\begin{array}{l}\text { The process of } \\
\text { traditional and } \\
\text { experiential learning } \\
\text { system }\end{array}$ & $\begin{array}{l}\text { Does interest in } \\
\text { entrepreneurship } \\
\text { grow }\end{array}$ \\
\hline 3 & $\begin{array}{l}\text { How are learning } \\
\text { strategies } \\
\text { implemented }\end{array}$ & $\begin{array}{l}\text { Learning system } \\
\text { increased student } \\
\text { interest in } \\
\text { entrepreneurship }\end{array}$ & $\begin{array}{l}\text { Opinion about } \\
\text { entreprenurship } \\
\text { course in Ciputra } \\
\text { University }\end{array}$ \\
\hline 4 & $\begin{array}{l}\text { EiR and Ciputra } \\
\text { University lecturers } \\
\text { selection process as } \\
\text { facilitators }\end{array}$ & $\begin{array}{l}\text { How students receive } \\
\text { learning materials }\end{array}$ & $\begin{array}{l}\text { The learning system } \\
\text { (traditional and } \\
\text { experiential learning) }\end{array}$ \\
\hline 5 & $\begin{array}{l}\text { Facilitator able to } \\
\text { become a role model }\end{array}$ & $\begin{array}{l}\text { Students' } \\
\text { Entrepreneurship } \\
\text { interests development }\end{array}$ & $\begin{array}{l}\text { Suggestion for the } \\
\text { learning system }\end{array}$ \\
\hline 6 & $\begin{array}{l}\text { Students accept } \\
\text { suggestions from the } \\
\text { facilitator }\end{array}$ & $\begin{array}{l}\text { Become a role model } \\
\text { for an entrepreneur }\end{array}$ & $\begin{array}{l}\text { Things learned in } \\
\text { Entrepreneurship } \\
\text { course }\end{array}$ \\
\hline 7 & $\begin{array}{l}\text { The increase of } \\
\text { Entrepreneurship } \\
\text { interest in student }\end{array}$ & $\begin{array}{l}\text { Students accept } \\
\text { suggestions from the } \\
\text { facilitator }\end{array}$ & Help from facilitator \\
\hline 8 & $\begin{array}{l}\text { Many groups } \\
\text { experience breakdown }\end{array}$ & $\begin{array}{l}\text { Many groups } \\
\text { experience breakdown }\end{array}$ & $\begin{array}{l}\text { Facilitator as role } \\
\text { model }\end{array}$ \\
\hline 9 & $\begin{array}{l}\text { Evaluation of the } \\
\text { learning system }\end{array}$ & & $\begin{array}{l}\text { Progress in the group } \\
\text { project }\end{array}$ \\
\hline
\end{tabular}

Source: Data Processed

This fact is contradictive with the previous research that conducted by Rosmiati, Junias, and Munawar (2015) that show a research result that the first semester accounting students is less intention in entrepreneurship because of most of the students in Politeknik Negeri Kupang does not really know and understand what entrepreneurship is. We can see a fact that entrepreneurship intention before joining entrepreneurship course is so important. The entrepreneurship intention will be a guidance for the students to learn more and want to know more about entrepreneurship.

The researcher also finds a fact that there are a lot of factors that can cause students break their entrepreneurial project such as different passion, the interpersonal relationship between the founder and the co- 
founder or the partner that does not contribute. Students tend to break their entrepreneurial project group if they have personal reason or personal matter between one person with the other person. For example, comment from respondent $\mathrm{F}$ : "Ya, kalau pecah kelompok itu bisa terjadi beberapa hal. Yang pertama misalnya, perbedaan misi dan visi ya kan, jadi yang anak satu sama anak yang lain mungkin beda, maunya beda. Yang kedua, biasanya sih ada yang free rider, gitu kan jadi iri-iri an, gitu kan, itu yang memicu konflik. Eee yang ketiga mungkin ada pembagian tugas atau job yang tidak balance, ada yang terlalu berat ada yangnggak ngapa-ngapain gitu kan, itu juga bisa memicu konflik. Artinya tidak ada, ada ketidakseimbanganlah disana antara kondisi satu dengan yang lain." Responden $S$ also give her opinion: "Macam-macam, jadi ada yang karena temen-temennya nggak kerja, ada yang karena dianya yang nggak kerja jadi disuruh pindah atau dikeluarin, atau karena banyak ditegur marah jadi akhirnya minta pindah padahal dia yang nggak kerja, Terus ese ada yang bidangnya itu dia sebenernya suka, tapi nggak cocok dengan, nggak cocok dengan". The researcher also can see a fact that most of entrepreneurship project decide to separate is not about the entrepreneurship intention.

There are seven main factors that supported entrepreneurial intention, first is risk taking (Remeikiene, Startiene \& Dumciuviene, 2013). The interview result shows that one of the entrepreneurship competencies that Ciputra University wants to teach to the students is risk taking. Risk taking is also one important step to develop business. One of the informants, A said that she does not afraid anymore: "ya apa ya, jadi lebih berani se, soalnya kan sudah pernah gagal dan kalo gagal itu sudah biasa, jadi yang penting niat untuk coba lagi se". So, from the experience of failing, students are given the spirit to keep trying again, because failure will definitely be experienced in doing business. It means students are encouraged to take the risk in running the business. The researcher can conclude that the risk-taking factor has been taught in Ciputra University and some of the students have this factor from entrepreneurial course.

The second factor is self-efficacy, it can be defined as a condition where people tend to produce a desired effect, and it concludes five dimensions: searching, planning, marshaling, implementing people, and implementing finance. Based on the interview result students learn about those five dimensions in Ciputra University, all of those five dimensions are delivered to the students by several approaching and method. Here is the comment from respondent $A$ : "Kalo di hard skillnya adalah bahwa mereka punya kemampuan, diharapkan Iho ya punya kemampuan empiric atau berdasarkan dicoba kan, itu kemampuannya adalah untuk bikin business plan, kemampuan untuk eksekusi business plan ya, kemampuan untuk apa namanya ngerti ada yang problem di di apa di bisnis saya terus inovasinya harus seperti apa. .... Ya tapi yang di pendidikan entrepreneurship yang dikejar adalah kemampuan untuk menciptakan business, menciptakan peluang, ngeliat peluang, ya terus the rest di urus 
sama jurusan." Similar with previous respondent, student S said: "Analisa Global analyzes, jadi global analyzes itu kita menganalisa key trend, eee terus makro, ekonomi makro. Terus kita juga menganalisa eee analisa industry, five forces porter itu, itu juga tapi untuk lingkup global ya."

Having said that, students can not the advance level because of the time limitation in entrepreneurship course. The researcher analyzes that time limitation is one of several things that can cause students not maximize their entrepreneurship intention. Students only meet with the facilitator once a week, even though students may meet the facilitator more than once a week but the students and the facilitator tend to have their own activity. Students also have another assignment beside entrepreneurship and the lecturer also have their own business or their own task. To overcome this problem, it might be possible to use mentor who is a fairly successful senior in running the business. So if students want to consult, it can also be through the senior directly.

The third factor is attitude. Based on the interview result, researcher can conclude that in Ciputra University students also learn about the importance of attitude, where students should dress neatly at every course. It is mentioned by respondent $P$ as follow: "Itu lak ya brarti kita disuruh berpakaian rapi." Students also have been taught about the ordinances talk when they meet a client. Respondent $\mathrm{P}$ also share his opinion: "Cara ngomong sama klien? Ya dapet seh, ada diomongi."

Attitude is one of several important things that can affect client decision. When client sees the businessman dress neatly and speak respectly, the client also will be respect and tend to believe student as a businessman. Ethics is also an important thing to be taught to students, how to meet other business people. "Di Uc kan kita diajarin kayak etika ketika kita bertemu dengan orang lain kita juga diperkenalkan dengan network-network yang UC kenal kayak gitu. Terus kita di encourage untuk memeperkenalkan bisnis kita, bikin business card, itu kan kalo ngga garagara tugas E mungkin aku juga ngga kepikiran gitu lho." It was the respond from respondent $A$. Ciputra University already realizes the importance and that's why students have been taught about attitude.

The next factor is behavioral control. Based on the interview result, students tend to control their own behave and build their own business. Students tend to know how important networking is in their daily activity and use it to develop business. This is proved by the comment from respondent A: "Emm kalo informally skill yang aku merasa dapet setelah ikut proses belajar E di UC adalah network. Itu paling aku syukuri sampe hari ini karena ternyata setelah aku lulus $E$ dan aku berbisnis sendiri yang membantuku berkembang itu bukan marketingku sendiri atau bukan kayak apa ya aku menginvestkan bener-bener untuk mempromosikan bisnisku, bikin training sekian kali serutin apa gitu."

Students tend to manage their behavior in front of people and stay humble to the other person. Ciputra University realized the importance of behavioral control to the business networking and up till now, Ciputra 
University always introduces their networking to the students. In this case, networking is an important instrument in learning entrepreneurship. Therefore, Ciputra University students are accustomed to having a wide network and must be accustomed to activities to expand existing networks.

Needs for achievement is also one of the seven factors of entrepreneurship intention. The research result shows a fact that students tend to achieve more by build her or his own business. This conclusion reported by respondent $\mathrm{R}$ as follow: "Eeee kalo dari yang sudah saya alamin ya 3 tahun 4 tahun disini mahasiswa yang aktif ini yang mereka bener-bener mempunyai motivasi dan apa ya kepingin jadi pengusaha, hasilnya justru mereka berprosenya cepet sekali." Entrepreneurship course also use this factor to motivate the students because based on the interview result, basically people will act if there is something to achieve. Students must achieve the target that the facilitator already set in entrepreneurship course, if they cannot reach the target, it will affect to their entrepreneurship course mark. However, basically it's not about the mark, but it will motivate students and so they will try to achieve the target. At the beginning students will see it as a burden, but after all they will realize the importance and tend to achieve more.

Opinion from respondent $\mathrm{C}$ support this argument: "Target ini lebih ke arah eee nggak hanya untuk E3 sih ya, secara umum manusia itu digerakan dengan tujuan kan. Kalau misalnya tanpa tujuanpun, mereka maksudnya mereka nggak tau mereka eksekusi ni ke arah mana dan targetnya sebenernya pun bukan angka yang besar. Jadi apabila mereka di ajak berpikir secara logis, ehm mereka tu sebenernya di target ee nominal terakhirnya tu 3.5 juta perbulan ketika bulan November. Eee kalo secara hitung-hitungan itu mereka perminggunya mungkin cuma harus profit 200ribuan kurang lebih segitu sih." So as facilitators, lecturers must provide understanding to students to be able to determine the right target, a reasonable amount to fulfill, so it is not too easy to achieve, but not too difficult to fulfill. By providing this understanding, students will be motivated if they experience failure. The responsibility of the facilitator certainly provides a logical understanding of the planning that has been made that the figure makes sense to be achieved and provides alternative choices of solutions to achieve the target lags.

The next factor is proactiveness. Proactiveness is have an entrepreneurial behavioral intention. Based on the interview result only one of the students that mention about this factor. She tends to take responsibility and do what necessary to her entrepreneurial project. She tends to learn and have proactiveness. Even though at the beginning she does not understand and know about operational thing, but right know she must be proactive and learn about the operational things. This is what responden F said: "Aku sih lebih tau carane ngambil keputusan, soale kan aku kan sebener e finance, tapi tementu yang production itu kan pergi ke study ke Korea, jadi kan aku yang nge back up. Terus jadine ya itu apa, kan aku yang contact langsung sama supplier e. Jadi lak ada apa-apa 
semua ne malah setelah aku ngomong mbe anak-anak, kalo misal e anakanak oke gini, apa namane kayak anak-anak yawis terserah kamu, sak sak apik e ya apa, ya itu malah mau ngga mau aku ambil keputusan." This trait is indeed not much owned by students, it means there are not many students who have an active nature behavior to find information even before facing problems. This is certainly the responsibility of the facilitator and the team in providing guidance to familiarize students with activity that will trigger them to becoming more active in running their business.

The seventh factor is locus of control, where students can control of their own self, so the success depends on their own action. Ciputra University also taught about locus of control where students prepared to control their self and realize that the success on their own hand. In entrepreneurship 1, students will be know more about herself or himself and then in entrepreneurship 2, students will creating idea, and start from entrepreneurship 3 until entrepreneurship 5 students will try to make their own businesses and know how to control them. As what mentioned by respondent B: "Jadi, jadi ceritanya tu gini E 1233 itu mahasiswa dipersiapkan ehmm untuk melakukan eeee proses penciptaan bisnis jadi mangkanya diawal ada persiapan tentang pribadi itu E1 kan, semua yang, yang sifatanya pengembangan diri itu dilakukan di e1. Di e2 itu kan konsentrasinya adalah penciptaan ide... ide bisnisnya dan segala macem yaa ditaruh e 2. E3 itu konsentrasinya di eksekusi."

At the other side, Respondent $C$ also said that in entrepreneurship course, students control their own business, know about SOP, marketing and human resource and then implement it on their own business: "Kalo tujuannya E3 ehmm mahasiswa memiliki pengalaman untuk startup bisnis, eksekusi bisnis. Kalo dari arah skill mereka mampu membuat SOP, mereka mampu menghadapi konflik di dalam team, mereka menguasai pengetahuan di bidang marketing dan mampu mengimplementasikan di project bisnis, eee marketing ini mencakup juga tentang digital marketing ya. Lalu dari sisi human resource diharapkan mereka punya pengetahuannya bagaimana merekrut dan seleksi, kalo memang ada yang perlu sampe implementasi ya diimplementasikan, eee kurang lebih itu sih". Based on the statement, researcher found a fact that in entrepreneurship course, students also execute and control their own business. Based on the discussion, researcher can see that all of entrepreneurship factor through intention has been taught in Ciputra University, but the result depends on the student itself.

Entrepreneurship is teachable and learnable and there are three ways to approach it. First, normative approach it can be defined as where the lecturer teaching and monitoring the production process of business plan. Starts from the second semester, students already learn about business idea and business plan, after that they will develop it until the global level. They also learn to search product what market need and accept, try to give impact for the product and design a strategy to develop it. This concept argued by the coordinator, respondent B: "Kalo di hard 
skillnya adalah bahwa mereka punya kemampuan, diharapkan tho ya punya kemampuan empiric atau berdasarkan dicoba kan, itu kemampuannya adalah untuk bikin business plan....the rest di urus sama jurusan." and respondent C: "Kalau entrepreneurship pasti menggabungkan antara teori dan praktek. Diharapkan mahasiswa ehmm bisa mengaplikasikan teori yang di dapat di start up bisnisnya. Apalagi tema E3 kan startup bisnis, yaitu mereka harus eksekusi business model yang sudah mereka rencanakan di E2."

And usually the facilitators give a comprehension about the theory, and after all students will try it and implicate it in their own business. This is mentioned by respondent P: "Pas seh benere dari praktek e dan ndak kebanyakan teori". From those statements researcher can conclude that entrepreneurship course in Ciputra University use Normative Approach to give the entrepreneurship education to the students.

The second approaching that can be used is experiental approach, where students learn knowledge, skills, attitudes, and insight based on the daily experiences. In entrepreneurship course, students must run their own entrepreneurship project and manage it. Students will experience how to run an entrepreneurial project by themselves. Facilitator will give direction and advice to solve the business problems, they also give advice to develop the business, but the one who execute the business is the student. When they experience it, they will know what kind obstacles that they will face and how to overcome it. Facilitators just monitor the business and give some suggestions.

Respondent A said because of entrepreneurship course, she experienced meet a lot of people and most of them become her client: "Jadi gara - gara tuntutan E intinya aku jadi kenal banyak orang yang tidak pernah aku bayangkan akan aku kenal. Dan setelah aku lulus E malah sebgaian mereka tu jadi klienku“ Other student, respondent $P$ also feels the same, because of the entrepreneurial course he can sell his products and know to to face people. "Maksude ya berkembang sih, maksude dari awal ya isa njual cuma e sekarang isa ngerti gitu tho nek misal e ngadepi orang tu ya apa cara ne."

Based on the data analysis, Ciputra University also used this approaching where students experienced a lot in their entrepreneur project. The coordinator of entrepreneurship course, Respondent B also mention about the project execution, where students execute their own business plan so the students can learn more how to face the problem and how to develop and innovate the business: "Ya persiapan dan 4 dan 5 itu lebih banyak ke eksekusi ke apa yang pendekatan dengan prodi. Kalo di hard ... kemampuan untuk eksekusi business plan ya, kemampuan untuk apa namanya ngerti ada yang problem di di apa di bisnis saya terus inovasinya harus seperti apa. ... sama jurusan." The statement is contradiction with Respondent $\mathrm{R}$ that said entrepreneurship course curriculum less supported on the excecution. "Ya ehmm, kalo saya lihat sih mungkin saya ngrasain di kurikulumnya itu eee terlalu apa ya eee 
kurang mendukung untuk kegiatan di eksekusinya. Jadi sebenernya actionya ini yang harus harus banyak berprosesnya itu yang harus fokus disana." He also suggests that the entrepreneurship curriculum should be more focusing in the action and the entrepreneurship process.

The researcher see that the entrepreneurship course curriculum is less supported on execution because of the time limitation, because of students only meet the facilitator once a week, sometimes students cannot maximize their entrepreneurship project. The facilitators also have their own business and have their own task, they cannot always monitoring the student entrepreneurial project, so it can be one of several reasons that entrepreneurship course curriculum is less supported on execution.

The last approach is contingency approach where students can learn based on case. Ciputra University also use this approach where the facilitator use several creative method such as switch class, simulation game, and also benchmarking with the competitor company. The facilitator makes the approaching became interesting by use several interested method. Opinion from respondent B: "Ini sekarang sekarang ngasih mata pelajarannya itu di switch. Yang tadinya dikasih di kelas, sekarang mahasiswa disuruh nyari sendiri. Mereka nyari sendiri, liat sendiri, dikasih video untuk liat, begitu masuk ke kelas itu dia tinggal di summarize, summary nya apa terus di diskusikan, ayo kalo programnya gini, projectnya gini, gimana? Ya jadi agak beda dikit, itu yang namanya switch class hee." Beside of the switch class method, the facilitator also use the simulation games method, so the students can take a reflection from that game. "Ehmm apa yang kita lakukan ketika materi conflict management kita bentuk dalam simulasi games. Dimana mereka akan refleksi, terus materi SOP rencananya ini kan belum kejadian, nanti beberapa minggu kedepan kita mau ajak mereka ke lapangan melihat eee SOP tu dibuat seperti apa dan bagaimana implementasinya seperti itu sih" as what mentioned from respondent $\mathrm{C}$.

The entrepreneurship course facilitators always develop the method and those methods show different result between one approaching with the other approaching. The result depends on the students itself, because according to the interview result, the effective method is different between one generation with the other generation, so the facilitator must give appropriate method so the students will know more about entrepreneurship.

Ciputra University has 2 types of facilitator, lecturer and EiR that hopefully can help students to learn theory and practical things at the same time. According to the interview result, this type of facilitator was chosen because with 2 type of facilitator, hopefully students can learn theory and practical things at the same time. As what explained by respondent $\mathrm{N}$ : "Eeee untuk $\mathrm{EiR}$, itu kita ambil supaya karena ini kan project ya, jadi eee supaya lebih pembimbingannya itu lebih realistis sesuai dengan trend yang sekarang terjadi di luar, dibidang tersebut, itu untuk mengimbangi dengan tenaga yang dosen." Strengthened by 
respondent C: "Cuma kalo secara logika aja, karena kita memang mengkombinasikan teori dan praktek harapannya bukan brarti dosen tidak tau prakteknya tapi kami lebih berharap EiR ini bisa lebih memberikan apa ya root of thumb atau hal-hal yang biasa terjadi di lapangan yang mungkin tidak tampak secara teori."

Having said that, some of the facilitator cannot be a good role model for students. This result related to the Christina, Purwoko, and Kusumowidagdo (2015) research that says it is important to determine the Entrepreneurship in Residence (EiR), they must able to guide, explain the added value and increase the students' learning intention. According to the interview result, the facilitators affect the developing of entrepreneurship intention of the student. The facilitator should be a good role model of the student and give several suggestions to the student so they can solve their entrepreneurial project problem. Facilitator also should tell his or her own business experience, so the students can learn from those experiences. But, sometimes the reality is slightly different. Some of the lecturer cannot be a good role model, but to overcome this matter, the SEH already take an action. Every half of the semester SEH usually do an evaluation that filled by the students. If the facilitator cannot be a good role model for the students and the students give a bad mark on them repeatly, they usually do not invite the facilitator into entrepreneurship course anymore.

\section{CONCLUSSION}

Ciputra University used and mixed the three entrepreneurial educations approaches; they are normative approach, experimental approach, and contingency approach. The entrepreneurial course facilitators already try several method that may develop the entrepreneurial intention of the student, but the result of the method depends on the students itself. Researcher also can take a conclusion that there are 2 types of facilitator, lecturer and EiR, this type of lecturer is chosen because of the facilitator can help students to learn both of theory and practical things. After all, the development of entrepreneurship intention of the student through entrepreneurship course in Ciputra University is different between one student with the other student. Entrepreneurship intention is so important and it will be a guidance for the students to learn more and want to know more about entrepreneurship, accordingly to the opinion that Entrepreneurial intention is a conscious awareness and conviction that people have to make a new business and make it real at the future (Gek, 2014). The type of this research is qualitative method using limited respondents. In the future, other researchers may use mixed methods in their research or use comparative studies between several different universities that equally apply entrepreneurial learning.

\section{REFERENCES}

Astebro, T., Herz, H., Nanda, R. \& Weber, R. A., (2014). Seeking the roots of 
entrepreneurship: Insights from behavioral economics. Journal of Economic Perspectives. 28(3), 49-70.

Azwar, S. (2012). Reliabilitas dan Validitas, Edisi 4. Yogyakarta: Pustaka Pelajar. Chandra, R. (2013). MBA in Entrepreneurship. Munich: BookRix.

Christina, W., Purwoko, H., \& Kusumowidagdo, A. (2015). The Role of Entrepreneur in Residence towards the Students' Entrepreneurial Performance: A Study of Entrepreneurship Learning Process at Ciputra University. Indonesia. Social and Behavioral Sciences. 211, 972-976. https://doi.org/10.1016/j.sbspro.2015.11.129

Efrata, T. C., Hadiwidjojo, D., Solimun, \& Aisjah, S. (2016). Entrepreneurship Education and Entrepreneurial Role Models: How do they affect Entrepreneurial Intentions? (Studies at Management and Business Students in Indonesia Universities). Australian Journal of Basic and Applied Sciences, 10(8), 53-59.

Ekpiken, W. E. \& Ukpabio, G. U. (2015). Entrepreneurship Education, Job Creation for Graduate Employment in South-South Geopolitical Zone of Nigeria. British Journal of Education. 3(1), 23-31.

Eroglu, O \& Picak, M. (2011). Entrepreneuship, National Culture and Turkey, International Journal of Business and Social Science. 2(16), 146-151.

Gek, M. O. (2014). Entrepreneurship Education Programs and Impacts on Business Performance. Deuctschland: Lap Lambert Academic Publishing.

Hongdiyanto, C. (2014). The identification of small medium enterprise (SME) owner entrepreneurship characteristic by using entrepreneurial marketing approach, Manajemen dan Bisnis Berkala IImiah, 13(1), 15-26.

Hongdiyanto, C. (2018). Exploration of Opportunity Creation and Calculated Risk Taker Characteristics of Entrepreneur (Case Study of UD X). International Journal of Innovation, Management and Technology, 9(3), 130-134

Hongdiyanto, C. (2018). Personal and Social Attributes as Determinants of Entrepreneurial Intention. Expert Journal of Business and Management. 6(2), 93-100.

Jerinabi, U., \& Shanti, P. (2012). Creativity, Innovation and Entrepreneurship. New Delhi: Allied Publisher.

Kelley, D., Singer, S., \& Herrington, M. (2016). 2015/16 Global Report. Massachusetts: Global Entrepreneurship Research Association.

Patricia, \& Silangen, C. (2016). The Effect of Entrepreneurship Education on Entrepreneurial Intention in Indonesia. DeReMa Jurnal Manajemen, 11(1), 67-83. https://doi.org/10.19166/derema.v11i1.184

Punch, K. F. (2013). Introduction to Research Methods in Education. Los Angeles: Sage.

Purwanto, M. I. (2015). Pengaruh Kompetensi Dosen dan Sikap Mahasiswa Pada Mata Kuliah Kewirausahaan Terhadap Tumbuhnya Jiwa Entrepreneur Mahasiswa dalam Penerapan Project Based Learning. Jurnal Probisnis. 8, 1-13.

Remeikiene, R., Strartiene, G., \& Dumciuviene, D. (2013). Explaining Entrepreneurial Intention of University Students: The Role of Entrepreneurial Education. International Journal of Management, Knowledge, and Learning, 299-307.

Rosmiati, Junias, D. T., \& Munawar. (2015). Sikap, Motivasi, dan Minat Berwirausaha Mahasiswa. Jurnal Manajemen dan Kewirausahaan, 17, 21-30. https://doi.org/10.9744/jmk.17.1.21-30 
Sugiyono. (2013). Metode Penelitian Kuantitatif Kualitatif dan R\&D. Bandung: Alfabeta.

Sujarweni, V. W. (2014). Metodologi Penelitian: Lengkap, Praktis, dan Mudah Dipahami. Yogyakarta: Pustaka Baru Press.

Szopa, A., Karwowski, W., \& Barbe, D. (2015). Competitive Strategies for Academic Entrepreneurship: Commercialization of Research- Based Products. Hershey: IGI Global.

Weber, R. (2012). Evaluating Entrepreneurship Education. Munchen: Springer Science \& Business Media. 